\title{
Total replacement of the soybean meal with extruded semi-whole soybean in the piglets feeding during the nursery phase
}

\section{Substituição total do farelo de soja com soja semi-integral extrusada na alimentação de leitões durante a fase de creche}

\author{
Maria Eliza Brumatti Galiardi ${ }^{*}$; Jansller Luiz Genova ${ }^{2}$; Paulo Levi de Oliveira \\ Carvalho $^{3}$; Isabela Ferreira Leal ${ }^{4}$; Petrônio Pinheiro Porto ${ }^{5}$; Liliana Bury de \\ Azevedo dos Santos ${ }^{6}$; Diovani Paiano ${ }^{7}$; Marcos Augusto Alves da Silva ${ }^{5}$
}

\begin{abstract}
The objective of this study was to evaluate the total replacement of soybean meal (SM) with extruded semi-whole soybean (ESWS) and its effects on feed digestibility, growth performance, plasma urea concentration (PUC) and economic feasibility. In Experiment I, a digestibility assay was undertaken using 12 crossbred pigs with an initial average body weight (IABW) of $18.85 \pm 0.69 \mathrm{~kg}$, distributed in a completely randomized design (CRD), with two treatments (reference diet and replacement of $30 \%$ of the reference diet by ESWS), six replicates and one pig per experimental unit. Experiment II involved 64 crossbred piglets, entire males, with an IABW of $7.46 \pm 0.55 \mathrm{~kg}$, distributed in a CRD, with two treatments (a control diet containing SM and another in which ESWS replaced SM), eight replicates and four animals per experimental unit. The digestible contents of dry matter, crude protein and gross energy of ESWS were $91.26 \%, 42.21 \%$ and $4,629 \mathrm{kcal} \mathrm{kg}^{-1}$, and the digestibility coefficients were $92.33 \%$, $96.49 \%$ and $91.21 \%$, respectively. Experiment II data indicated an effect on the feed conversion (FC) in the total period, in which pigs fed SM presented better FC. The diets affected the PUC in the pre-starter II phase and the total period, with pigs fed SM showing higher PUC. The cost of feed per kilogram of live weight gain increased in the starter phase. ESWS does not change the DWG and ADFI of piglets but worsens both the FC in the total period and economic results.
\end{abstract}

Key words: Alternative food. Economic feasibility. Growth performance. Plasma urea. Soybean byproducts.

\section{Resumo}

O objetivo deste estudo foi o de avaliar a substituição total do farelo de soja (FS) com soja semiintegral extrusada (SSIE) e seus efeitos na digestibilidade das rações, no desempenho zootécnico, na ureia plasmática e na viabilidade econômica. Um ensaio de digestibilidade foi realizado usando 12 suínos mestiços com peso corporal inicial médio (PCIM) de 18,85 $\pm 0,69 \mathrm{~kg}$, distribuídos em um delineamento inteiramente casualizado (DIC), com dois tratamentos (dieta referência e substituição

${ }^{1}$ M.e em Agronomia, Universidade Estadual do Norte do Paraná, UENP, Bandeirantes, PR, Brasil. E-mail: mariaeliza@uenp.edu.br

2 M.e em Zootecnia, Universidade Estadual do Oeste do Paraná, UNIOESTE, Marechal Cândido Rondon, PR, Brasil. E-mail: jansllerg@gmail.com

3 Prof. Dr., UNIOESTE, Marechal Cândido Rondon, PR, Brasil. E-mail: paulolevi@yahoo.com.br

4 M.e em Zootecnia, Universidade Estadual de Maringá, UEM, Maringá, PR, Brasil. E-mail: isabelafleal@gmail.com

5 Profs. Drs., UENP, Bandeirantes, PR, Brasil. E-mail: petronio@uenp.edu.br; marcossilva@uenp.edu.br

M.e em Zootecnia, UNIOESTE, Marechal Cândido Rondon, PR, Brasil. E-mail: liliana.bury@hotmail.com

7 Prof. Dr., Universidade do Estado de Santa Catarina, UDESC, Chapecó, Santa Catarina, Brasil. E-mail: diovani.paiano@udesc.br

* Author for correspondence 
de $30 \%$ da dieta referência pela SSIE), seis repetições e um suíno por unidade experimental. Para o desempenho zootécnico (Exp. II), foram utilizados 64 leitões mestiços, machos inteiros, com PCIM de $7,46 \pm 0,55 \mathrm{~kg}$, distribuídos em DIC, com dois tratamentos (dieta controle contendo FS e outra em que o FS foi substituído pela SSIE), oito repetições e quatro animais por unidade experimental. Os teores digestíveis de matéria seca, proteína bruta e energia bruta da SSIE foram de $91,26 \%, 42,21 \%$ e 4.629 $\mathrm{kcal} \mathrm{kg}^{-1}$, e os coeficientes de digestibilidade foram de $92,33 \%, 96,49 \%, 91,21 \%$, respectivamente. Os resultados do Exp. II indicam um efeito na conversão alimentar (CA) no período total, em que os suínos alimentados com FS apresentaram melhor CA. Houve diferença na concentração de ureia plasmática (CUP) na fase pré-inicial II e no período total, e os suínos alimentados com o FS apresentaram maior CUP. O custo da ração por quilograma de peso vivo ganho aumentou na fase inicial. A SSIE não altera o GDP e o CDR dos leitões, mas piora a CA no período total e nos resultados econômicos.

Palavras-chave: Alimentos alternativos. Viabilidade econômica. Desempenho zooténico. Ureia plasmática. Co-produtos da soja.

\section{Introduction}

In the nutrition of non-ruminant animals, soybean meal $(\mathrm{SM})$ is considered the main protein ingredient in the preparation of feed. However, the full soybean has also been widely used as a possible alternative food in diets, due to its high ethereal extract content and metabolizable energy (ME) (LEITE et al., 2012).

However, the soybean grain must be heat-treated before its inclusion in the diet of non-ruminant animals because of the presence of antinutritional factors that interfere with the digestibility, assimilation or utilization of the nutrients by the animal metabolism (BUTOLO, 2010).

Soybean processing methods produce several products with different nutritional characteristics, and it is of great importance to understand the physical-chemical changes so that the nutritional requirements of the animals are met (BERTIPAGLIA et al., 2008).

Among the types of processing, the toasting by steam and extrusion stand out (SAKOMURA et al., 2004). The basic principle of extrusion is the conversion of solid material into a liquid by the application of heat and mechanical force, impelling its passage through a matrix and producing a product with predetermined characteristics (SEBIO, 1996).

This processing inactivates the antinutritional factors of raw soybean and increases the digestibility of the oil (FEDALTO et al., 1999). For the soybean improvement, it is the process that presents the best nutritional characteristics of the food (BELLAVER; SNIZEK JÚNIOR, 1999).

In this context, our objective in this study was to evaluate the total replacement of SM with extruded semi-whole soybean (ESWS), and its effects on feed digestibility, growth performance, plasma urea concentration (PUC) and economic feasibility.

\section{Material and Methods}

The experiment was carried out at the Swine Sector of the Experimental Station Nucleus of the State University of Western Paraná, Unioeste, Campus of Marechal Cândido Rondon (Cândido Rondon, Paraná, Brazil). The study was approved by the Ethics Committee on the Use of Animals of Unioeste (number: 55/17).

\section{Experimental design, animals, housing and diets}

In the digestibility assay (Experiment I), a total of 24 crossbred pigs, entire male, with an initial average body weight of $18.85 \pm 0.69 \mathrm{~kg}$, were distributed in a completely randomized design, with two treatments and six replicates, totaling 12 experimental units.

The animals were housed individually in metabolic cages similar to those described 
previously by Pekas (1968), in which they remained for 11 days; 6 days for acclimation to cages and feed, and 5 days for collection of feces and urine.

The temperature of the shed was monitored by a digital table thermometer, and the temperature was regulated by opening and closing of curtains and using fans, registering minimum and maximum temperatures of 23.2 and $35.4^{\circ} \mathrm{C}$, respectively, which were recorded at 09:00 am and 03:00 pm.
The evaluated food was obtained by processing it through a Bindgalvão ${ }^{\circledR}$ Extruder Press, which extracts the cold oil without chemical processing and performs the extrusion through a thermal and physical process of pressure and friction. The ESWS replaced, based on the natural matter, was $30 \%$ of the reference feed (RF), which resulted in an RF and a test feed (TF). The RF (Table 1) was formulated according to the chemical composition and energy values of the ingredients indicated by Rostagno et al. (2011).

Table 1. Centesimal composition of reference diet.

\begin{tabular}{lc}
\hline Ingredient & $\%$ \\
\hline Corn & 63.82 \\
Soybean meal 45.22\% & 30.56 \\
Soybean oil & 1.19 \\
Phosphate mono/dicalcium & 1.54 \\
Limestone & 1.09 \\
Common salt & 0.44 \\
Mineral and vitamin premix ${ }^{1}$ & 0.50 \\
Lysine sulfate & 0.58 \\
DL-Methionine & 0.14 \\
L-Threonine & 0.13 \\
L-Tryptophan & 0.01 \\
\hline Total & 100 \\
\hline & \\
\hline Nutrient & \\
\hline Calcium, \%eeting the nutritional requirements & 0.83 \\
Metabolizable energy, kcal/kg & 3.23 \\
Available phosphorus, \% & 0.41 \\
Digestible lysine, \% & 1.21 \\
Digestible methionine + cysteine, \% & 0.68 \\
Crude protein, \% & 19.50 \\
Sodium, \% & 0.20 \\
Digestible threonine, \% & 0.76 \\
Digestible tryptophan, \% & 0.22 \\
\hline M $\%$ & \\
\hline
\end{tabular}

${ }^{1}$ Mineral and vitamin premix - Warranty levels (minimum) per kg of product: folic acid $103.12 \mathrm{mg}$; pantothenic acid 2249.99 mg; butylated hydroxytoluene $100.00 \mathrm{mg}$; biotin $16.88 \mathrm{mg}$; chlorohydroxyquinoline $15.00 \mathrm{~g}$; copper $22.87 \mathrm{~g}$; iron $6733.40 \mathrm{mg}$; phytase $50000,00 \mathrm{U}$; glucanase $1900.00 \mathrm{U}$; iodine $37.50 \mathrm{mg}$; lysine $122.50 \mathrm{~g}$; manganese $1866.70 \mathrm{mg}$; methionine $110.30 \mathrm{~g}$; niacin 4687.50 mg; selenium $43.75 \mathrm{mg}$; threonine $46.40 \mathrm{~g}$; vitamin A $14375.00 \mathrm{UI}$; vitamin $\mathrm{B}_{1} 224.95 \mathrm{mg}$; vitamin $\mathrm{B}_{6} 437.50 \mathrm{mg}$; vitamin $\mathrm{D}_{3}$ $262500.00 \mathrm{UI}$; vitamin E $4250.00 \mathrm{UI}$; vitamin $\mathrm{K}_{3} 375.00 \mathrm{mg}$; xylanase $152500.00 \mathrm{U}$; zinc $1000.00 \mathrm{mg}$. 
During the acclimation phase, the animals received two meals per day, provided at 08:00 am and at 03:00 pm. The total daily amount of food provided during the collection period was determined from the acclimation period, based on the animals' voluntary consumption and metabolic weight $\left(\mathrm{BW}^{0.75}\right)$. The feed was moistened with water ( $20 \%$ by total weight of feed) to avoid waste, reduce powdery properties and improve palatability. After each meal, water was supplied through a feeder at a rate of $3 \mathrm{~mL} / \mathrm{g}$ of feed consumed; the quantity was calculated for each experimental unit to avoid excess water consumption.
For the growth performance trial (Experiment II), 64 crossbred piglets, entire males, weaned at 21 days old, with an initial average body weight of $7.46 \pm 0.55 \mathrm{~kg}$, were distributed in a completely randomized design, with eight replicates of four piglets per experimental unit.

The experimental treatments consisted of two isoenergetic, isocalcium, isophosphoric and isoaminoacid feeds. A control diet containing SM was used, and another in which the SM was completely replaced (100\%) by ESWS. Feeds were formulated according to the growing phases (Table 2) reported by Rostagno et al. (2011).

Table 2. Composition of pre-starter I, pre-starter II and starter feeds containing soybean meal (SM) or extruded semiwhole soybean (ESWS) provided for piglets.

\begin{tabular}{|c|c|c|c|c|c|c|}
\hline \multirow[t]{2}{*}{ Ingredient } & \multicolumn{2}{|c|}{$\begin{array}{c}\text { Pre-starter I } \\
\text { (21 to } 30 \text { days) } \\
\end{array}$} & \multicolumn{2}{|c|}{$\begin{array}{l}\text { Pre-starter II } \\
\text { (30 to } 39 \text { days) } \\
\end{array}$} & \multicolumn{2}{|c|}{$\begin{array}{c}\text { Starter } \\
\text { (39 to } 57 \text { days) }\end{array}$} \\
\hline & SM & ESWS & SM & ESWS & SM & ESWS \\
\hline Corn & 52.92 & 63.22 & 54.88 & 69.49 & 65.90 & 76.61 \\
\hline Whey & 20.00 & 20.00 & 12.73 & 12.73 & - & - \\
\hline SM 45.22\% & 15.11 & - & 21.30 & - & 26.49 & - \\
\hline ESWS & - & 9.84 & - & 10.67 & - & 15.83 \\
\hline Sugar & 4.00 & - & 3.00 & - & - & - \\
\hline Fish meal 53\% & 3.00 & 3.00 & 3.00 & 3.00 & 3.00 & 3.00 \\
\hline Soybean oil & 1.59 & - & 2.09 & - & 0.85 & - \\
\hline Dicalcium phosphate & 1.50 & 1.65 & 1.12 & 1.33 & 1.21 & 1.50 \\
\hline Mineral and vitamin premix ${ }^{1}$ & 0.50 & 0.50 & 0.50 & 0.50 & 0.50 & 0.50 \\
\hline Common salt & 0.40 & 0.40 & 0.34 & 0.34 & 0.39 & 0.40 \\
\hline Limestone & 0.30 & 0.30 & 0.62 & 0.61 & 0.70 & 0.67 \\
\hline DL-Methionine & 0.19 & 0.22 & 0.13 & 0.22 & 0.14 & 0.25 \\
\hline Lysine sulfate $55 \%$ & 0.17 & 0.39 & 0.19 & 0.64 & 0.62 & 1.10 \\
\hline L-Valine & 0.16 & 0.23 & - & 0.17 & 0.05 & 0.25 \\
\hline L-Threonine & 0.12 & 0.18 & 0.08 & 0.21 & 0.14 & 0.30 \\
\hline L-Tryptophan & 0.05 & 0.08 & 0.02 & 0.08 & 0.02 & 0.09 \\
\hline Inert (washed sand) & - & - & - & - & - & 3.50 \\
\hline Total & 100 & 100 & 100 & 100 & 100 & 100 \\
\hline \multicolumn{7}{|c|}{ Meeting the nutritional requirements } \\
\hline \multicolumn{7}{|l|}{ Nutrients } \\
\hline Calcium, \% & 0.82 & 0.82 & 0.83 & 0.83 & 0.83 & 0.83 \\
\hline Metabolizable energy, kcal/kg & 3.40 & 3.40 & 3.38 & 3.38 & 3.23 & 3.23 \\
\hline
\end{tabular}


continuation

\begin{tabular}{lcccccc} 
Available phosphorus, \% & 0.55 & 0.55 & 0.45 & 0.45 & 0.41 & 0.41 \\
Digestible lysine, \% & 1.45 & 1.45 & 1.33 & 1.33 & 1.21 & 1.21 \\
Digestible methionine + cysteine, \% & 0.81 & 0.81 & 0.75 & 0.75 & 0.68 & 0.68 \\
Crude protein, \% & 20.00 & 18.46 & 20.25 & 16.98 & 19.50 & 15.52 \\
Sodium, \% & 0.28 & 0.28 & 0.23 & 0.23 & 0.20 & 0.20 \\
Digestible threonine, \% & 0.91 & 0.91 & 0.84 & 0.84 & 0.76 & 0.76 \\
Digestible tryptophan, \% & 0.26 & 0.26 & 0.24 & 0.24 & 0.22 & 0.22 \\
Digestible value, \% & 1.00 & 1.00 & 0.86 & 0.86 & 0.83 & 0.83 \\
\hline
\end{tabular}

${ }^{1}$ Mineral and vitamin premix - Warranty levels (minimum) per kg of product: folic acid $103.12 \mathrm{mg}$; pantothenic acid $2249.99 \mathrm{mg}$; butylated hydroxytoluene $100.00 \mathrm{mg}$; biotin $16.88 \mathrm{mg}$; chlorohydroxyquinoline $15.00 \mathrm{~g}$; copper $22.87 \mathrm{~g}$; iron $6733.40 \mathrm{mg}$; phytase 50000,00 U; glucanase $1900.00 \mathrm{U}$; iodine $37.50 \mathrm{mg}$; lysine $122.50 \mathrm{~g}$; manganese $1866.70 \mathrm{mg}$; methionine $110.30 \mathrm{~g}$; niacin 4687.50 mg; selenium $43.75 \mathrm{mg}$; threonine $46.40 \mathrm{~g}$; vitamin A $14375.00 \mathrm{UI}$; vitamin $\mathrm{B}_{1} 224.95 \mathrm{mg}$; vitamin $\mathrm{B}_{6} 437.50 \mathrm{mg}$; vitamin $\mathrm{D}_{3}$ $262500.00 \mathrm{UI}$; vitamin E $4250.00 \mathrm{UI}$; vitamin $\mathrm{K}_{3} 375.00 \mathrm{mg}$; xylanase $152500.00 \mathrm{U}$; zinc $1000.00 \mathrm{mg}$.

The animals were identified with numbered ear tags and housed in suspended nursery pens $(1.54$ $\mathrm{m}^{2}$ ), with polyethylene plastic flooring, equipped with nipple-type drinking fountains and semiautomatic feeders, and located in a masonry shed with concrete flooring, ceramic roof tiles and a heating system with lamps. Feed and water were provided ad libitum throughout the experimental period.

The minimum and maximum temperature values for the experimental period were 9.6 and $36.1^{\circ} \mathrm{C}$, respectively, according to data from the National Institute of Meteorology at the Station of Marechal Cândido Rondon (Paraná, Brazil).

\section{Sample collection and preparation}

In Experiment I, the amount of feed supplied, and the feces and urine sample collection followed the methods previously described by Sakomura and Rostagno (2016).

During the collection period, $1.5 \%$ of ferric oxide $\left(\mathrm{Fe}_{2} \mathrm{O}_{3}\right)$ was added to the feed, to mark the beginning and end of the fecal collection. Feces were collected daily, weighed, placed in labeled plastic bags and stored in a freezer at $-18^{\circ} \mathrm{C}$. After the collection period, fecal samples were thawed, homogenized, weighed on a digital scale, and a composite sample $(20 \%$ by total weight of feces) of that collected from each experimental unit was removed. Composite samples were dried in a forced ventilation oven $\left(55^{\circ} \mathrm{C}\right)$, ground in a Wiley-type grinder mill and stored in polyethylene pots, for analysis of dry matter (DM), organic matter (OM), mineral matter, gross energy (GE) and crude protein (CP). Analyses were carried out at the Unioeste's Animal Nutrition Laboratory (LANA).

Urine was collected daily in plastic buckets containing $20 \mathrm{~mL}$ of $1: 1 \mathrm{HCl}$ to avoid nitrogen volatilization and bacterial proliferation. An aliquot ( $10 \%$ by total volume of urine) was conditioned daily in polyethylene terephthalate bottles and frozen at $-18^{\circ} \mathrm{C}$. Subsequently, these samples were homogenized, and aliquots were taken for the determination of crude energy.

In Experiment II, the leftover feed was collected, weighed and subtracted from feed supplied to calculate daily feed intake. The individual weight of the animals was recorded on an electronic scale (Digitron ${ }^{\odot}$ brand, 50-kg capacity), at the beginning and end of each experimental phase.

Blood parameters were determined at the end of the pre-starter I and II phases, and starter phase. Blood samples were collected via the vena cava, 
using $0.70 \times 30 \mathrm{~mm}$ and $0.80 \times 40 \mathrm{~mm}$ gauge needles, into $5-\mathrm{mL}$ test tubes containing urea anticoagulant (ethylenediaminetetraacetic acid), according to the technique previously described by Cai et al. (1994). Blood samples were then sent to Unioeste's Blood Parameters Laboratory, and centrifuged (Centrifuge Excelsa ${ }^{\circledR}$ II, Model 206-R) at $3000 \mathrm{rpm}$ for $15 \mathrm{~min}$. The plasma was then transferred to Eppendorf polyethylene tubes, in duplicate, labeled, and then stored in a freezer at $-5^{\circ} \mathrm{C}$, awaiting further analysis.

\section{Analysed variables}

All analyses of food, urine and feces were performed following the procedures previously reported by Silva and de Queiroz (2002). In Experiment I, the dry matter digestibility coefficient (DMDC), organic matter digestibility coefficient (OMDC), crude protein digestibility coefficient (CPDC), gross energy digestibility coefficient (GEDC) and coefficient of metabolizable gross energy (GEMC) for ESWS were calculated according to procedures published by Moreira et al. (1994), and Sakomura and Rostagno (2016).

Digestible protein (DP), digestible dry matter (DDM), digestible organic matter (DOM), digestible energy (DE) and ME of the diets were calculated according to procedures published by Matterson et al. (1965). For comparison of the DDM, DP, DOM, DE and ME from ESWS with those found by Rostagno et al. (2011) and Thomaz et al. (2012), the values were converted to $100 \% \mathrm{DM}$.

In Experiment II, the average daily feed intake (ADFI, kg/day), daily weight gain (DWG, kg/day), feed conversion $(\mathrm{FC}, \mathrm{kg} / \mathrm{kg})$ and final weight $(\mathrm{kg} /$ phase) of each growing phase were calculated from the data of feed intake and weight gain of each experimental phase.

Urea was determined by using an automated biochemical analyzer (model Flexor EL 200) and the reagents supplied in specific ELI Tech kits (Clinical Systems).
To determine the economic viability, the prices of the ingredients used in the elaboration of the experimental diets were as follows: corn grain, R\$ 0.7268/kg; SM, R\$ 1.35/kg; ESWS, R\$ 1.35; soybean oil, R\$ 2.66/kg; fish meal, R\$ $2.00 / \mathrm{kg}$; dicalcium phosphate, $\mathrm{R} \$ 2.35 / \mathrm{kg}$; common salt, R\$ 0.46/kg; sugar, R\$ $1.876 / \mathrm{kg}$; vitamin-mineral premixes, R\$ 15.00/kg; L-lysine, R\$ 3.30/kg; DLmethionine, R\$ 17.50/kg; L-threonine, R\$ $7.01 / \mathrm{kg}$; L-tryptophan, R\$ 60.00/kg; L-valine, R\$ $28.00 / \mathrm{kg}$; inert, R\$ 0.20/kg.

\section{Economic feasibility and statistical analysis}

To verify the economic feasibility of replacing SM with ESWS, the feed cost per kilogram of live weight gain $\left(Y_{i}\right)$ was determined in the diets, according to Bellaver et al. (1985): $Y_{i}(\mathrm{R} \$ / \mathrm{kg})=\left(Q_{i}\right.$ $\left.\times P_{i}\right) / G_{i}$ ), wherein $Y_{i}=$ cost of the feed per kilogram of live weight gain in the $i$-th treatment; $P_{i}=$ price per kilogram of the feed used in the $i$-th treatment; $Q_{i}=$ amount of feed consumed in the $i$-th treatment, and $G_{i}=$ weight gain of the $i$-th treatment.

Calculations were then done to obtain the economic efficiency index (EEI) and the cost index (CI), as proposed by Gomes et al. (1991): EEI (\%) $\left.=\left(\mathrm{MC}_{e} / \mathrm{CT}_{e i}\right) \times 100\right)$, and $\mathrm{CI}(\%)=\left(\mathrm{CT}_{e l} / \mathrm{MC}_{e}\right) \times$ 100 , wherein $\mathrm{MC}_{e}=$ lower feed cost per kilogram gain observed between treatments, and $\mathrm{CT}_{e i}=$ cost of treatment $i$ considered.

For the growth performance characteristics, PUC and economic feasibility variables were submitted to analysis of variance, considering the mathematical model: $Y_{i k}=\mu+T_{i}+\varepsilon_{i k}$, wherein $Y_{i k}=$ observation $k$, receiving food $i ; \mu=$ general constant, associated with all observations; $T_{i}=$ effect $i$ of soybean meal (SM) replacement by extruded semi-whole soybean (ESWS); $\varepsilon_{i k}=$ random error associated with each observation $Y_{i k}$. To verify the differences between treatments, a Student's $t$-test was performed, considering the $5 \%$ probability level. 


\section{Results and Discussion}

\section{Digestibility assay}

The contents of DM, OM, CP and GE of ESWS were $91.26 \%, 85.91 \%, 42.21 \%, 8.53 \%$ and 4,629 $\mathrm{kcal} / \mathrm{kg}$, respectively, which were similar to the corresponding ESWS values described by Rostagno et al. (2011) of $90.50 \%, 85.44 \%, 40.07 \%, 8.32 \%$ and $4,161 \mathrm{kcal} / \mathrm{kg}$.

The variations in the GE values can be attributed to differences in the oil content in the grains and the extraction method used. The changes in the nutrient content of the food can be associated with several factors, such as the physical-chemical alterations in the food during processing and the type and conditions of the processing applied (BERTIPAGLIA et al., 2008).

In comparison, Thomaz et al. (2012) obtained higher values of EE (16.41\%) and GE (5,097.10 $\mathrm{kcal} \mathrm{kg}^{-1}$ ) for ESWS, whereas, Mendes et al. (2004) found values consistent with the current results, for the same variables of the same product, including a higher CP for ESWS compared with that recorded by Thomaz et al. (2012) for ESWS (39.72\%). Already, Castillo et al. (2001) stated that the CP of soybean byproducts could vary from $44 \%$ to $46 \%$.

It was observed that the OMDC, CPDC, GEDC and GEMC (Table 3) obtained for the ESWS were superior to those found by Rostagno et al. (2011) for SM and extruded whole soybean (EWS).

Table 3. Dry matter digestibility coefficient (DMDC), organic matter digestibility coefficient (OMDC), crude protein digestibility coefficient (CPDC), gross energy digestibility coefficient (GEDC) and the coefficient of metabolizable gross energy (GEMC) of soybean meal (SM), extruded whole soybean (EWS) and extruded semi-whole soybean (ESWS).

\begin{tabular}{lccc}
\hline Item & SM $^{\mathbf{1}}$ & EWS $^{\mathbf{1}}$ & ESWS \\
\hline DMDC, \% & - & - & 92.33 \\
OMDC, \% & 80.68 & 83.00 & 93.73 \\
CPDC, \% & 90.00 & 88.00 & 96.49 \\
GEDC, \% & 83.74 & 82.69 & 91.21 \\
GEMC, \% & 77.11 & 77.76 & 86.83 \\
\hline
\end{tabular}

${ }^{1}$ Values found by Rostagno et al. (2011).

In Mendes et al. (2004), the DMDC, CPDC and GEDC results for ESWS $(81.85 \%, 86.12 \%$ and $83.59 \%$ ) were also lower than those found in this study.

By comparing the CPDC (90.00\%), GEDC $(83.74 \%)$ and GEMC $(73.11 \%)$ for the SM of Rostagno et al. (2011) to the present study, it verified the availability of these nutrients in ESWS, because it presented a higher oil content, and the extrusion process improves the nutritional value of the soybean.

While Thomaz et al. (2012) observed lower DC for ESWS when compared to this study, the current findings corroborated with those provided by other authors (MENDES et al., 2004; ROSTAGNO et al., 2011).

The extrusion process acts to break the cell walls of the grain, thereby increasing its digestibility and the ME of the oil, deeming it the best method to eliminate undesirable factors, and the most efficient because it provides a greater exposure of the nutrients when compared with other techniques (BELLAVER; SNIZEK JÚNIOR, 1999; BRUMANO; GATTÁS, 2004; LEITE et al., 2012). 
The extrusion process makes the fat decomposition slower, favors the digestibility of the oil due to its greater availability to the animals and reduces the loss of vitamins (BELLAVER; SNIZEK JÚNIOR, 1999).
The levels of DDM, DOM and ME of ESWS (Table 4) were higher than the levels found by Rostagno et al. (2011) for SM and EWS. The DP of ESWS (44.63\%) was lower than SM (45.86) but higher than EWS (35.63\%). The ESWS DE (4,626 $\mathrm{kcal} / \mathrm{kg})$ was higher than that of SM $(3,859 \mathrm{kcal} / \mathrm{kg})$ but equal to that of EWS $(4,626 \mathrm{kcal} / \mathrm{kg})$.

Table 4. Contents of digestible dry matter (DDM), digestible organic matter (DOM), digestible protein (DP), digestible energy (DE) and metabolizable energy (ME) of soybean meal (SM), extruded whole soybean (EWS) and extruded semi-whole soybean (ESWS).

\begin{tabular}{lcccccc}
\hline Item & SM $^{\mathbf{1}}$ & $\mathbf{S M}^{\mathbf{2}}$ & EWS $^{\mathbf{1}}$ & EWS $^{\mathbf{2}}$ & ESWS $^{\mathbf{1}}$ & ESWS $^{\mathbf{2}}$ \\
\hline DDM, \% & - & - & - & - & 84.26 & 92.33 \\
DOM, \% & 66.9 & 75.38 & 70.83 & 78.75 & 80.52 & 88.23 \\
DP, $\%$ & 40.7 & 45.86 & 32.05 & 35.63 & 40.73 & 44.63 \\
DE, $\mathbf{k c a l} / \mathbf{k g}$ & 3,425 & 3,859 & 4,161 & 4,626 & 4,222 & 4,626 \\
ME, $\mathbf{k c a l} / \mathbf{k g}$ & 3,154 & 3,554 & 3,913 & 4,351 & 4,019 & 4,404 \\
\hline
\end{tabular}

${ }^{1}$ Values in natural matter. ${ }^{2}$ Values in $100 \%$ dry matter.

The DP in this experiment (44.63\%) was greater than the $38.14 \%$ determined by Moreira et al. (1994) for EWS, and $37.71 \%$ recorded by Thomaz et al. (2012) for ESWS.

For the DE $(4,626 \mathrm{kcal} / \mathrm{kg})$ and ME $(4,404 \mathrm{kcal} /$ $\mathrm{kg})$ in this experiment, respectively lower $(4,785$ $\mathrm{kcal} / \mathrm{kg})$ and similar $(4,399 \mathrm{kcal} / \mathrm{kg})$ data were reported by Moreira et al. (1994), whereas, Thomaz et al. (2012) noted higher numbers for both variables $(4,470$ and $4,278 \mathrm{kcal} / \mathrm{kg}$, respectively). This fact can be a reflection of the different byproducts, as well as the oil extraction methods used.

From the results obtained in this research, there was agreement with Bellaver and Snizek Júnior (1999), who reported that among the main processes of soybean processing, extrusion provides the best nutritional characteristics of the food.

According to Thomaz et al. (2012), the ESWS has good feasibility for piglet feeding in the starter phase, mainly because of the energy content, which shows high levels of DE and ME when compared with SM. Due to the high DE and ME, Castillo et al.
(2001) mentioned that ESWS is a viable ingredient in the formulation of pig feeds and can be used for partial or total replacement of SM.

\section{Growth performance}

Total replacement of SM by ESWS did not affect $(P>0.05)$ the ADFI and DWG variables in the pre-starter I phase and in the total period. However, for the FC variable, although there was no difference $(P>0.05)$ in the pre-starter I phase, there was an effect $(P<0.05)$ during the total period (Table 5), in which pigs fed SM presented better FC than those fed ESWS. Although ESWS presented good digestibility results, there was no difference $(P>0.05)$ in ADFI and DWG, and this is expected because all the feeds had the same nutritional values.

The factor that may have influenced the FC is the energy/protein ratio $(\mathrm{E} / \mathrm{P})$, because changes in the E/P may lead to a reduction or voluntary increase in the food intake. Thus, when there is some modification of the energy level of the diets, 
all the nutrients may have their intakes changed (REZENDE et al., 2006).

According to Bertol et al. (2001), the partial replacement of SM (50\%) by soybean byproducts for weaned piglets at 21 days of age, presented results similar to those found in our study in the pre-starter I phase, and the FC was lower in the treatment containing SM-EWS relative to the control. However, DWG was similar, demonstrating similar feed efficiency in all diets.

Table 5. Growth performance of piglets fed feeds containing soybean meal (SM) and extruded semi-whole soybean (ESWS) at different nursery phases.

\begin{tabular}{|c|c|c|c|}
\hline \multicolumn{4}{|c|}{ Pre-starter I } \\
\hline Item $^{1}$ & SM & ESWS & $\mathrm{CV}^{2}, \%$ \\
\hline IW & 7.49 & 7.43 & 19.77 \\
\hline FW & 9.62 & 9.53 & 23.74 \\
\hline ADFI & 0.31 & 0.30 & 16.53 \\
\hline DWG & 0.25 & 0.23 & 27.87 \\
\hline FC & 1.22 & 1.32 & 15.35 \\
\hline \multicolumn{4}{|c|}{ Total period } \\
\hline SW & 7.49 & 7.44 & 12.70 \\
\hline FW & 22.87 & 22.22 & 23.71 \\
\hline ADFI & 0.66 & 0.68 & 14.07 \\
\hline DWG & 0.43 & 0.41 & 31.76 \\
\hline FC & $1.53 \mathrm{~b}$ & $1.67 \mathrm{a}$ & 8.14 \\
\hline
\end{tabular}

${ }^{1}$ Initial weight (IW); final weight (FW, kg/phase); average daily feed intake (ADFI, kg/day); daily weight gain (DWG, kg/day); feed conversion $(\mathrm{FC}, \mathrm{kg} / \mathrm{kg}) .{ }^{2}$ Coefficient of variation. Means followed by different letters on the same line differ statistically by the Student's $t$-test at the $5 \%$ probability level.

\section{Plasma urea}

There was no difference $(P>0.05)$ in the PUC during the pre-starter I phase. In contrast, the type of diet affected $(P<0.05)$ the PUC in the pre-starter II phase and the total period, such that the SMfed pigs showed higher PUC than their ESWS-fed counterparts (Table 6).

Table 6. Plasma urea concentration of piglets $(\mathrm{mg} / \mathrm{dL})$ in the diets containing soybean meal (SM) and extruded semiwhole soybean (ESWS).

\begin{tabular}{lccc}
\hline Phase & SM & ESWS & CV $^{\mathbf{1}} \mathbf{\%}$ \\
\hline Pre-starter I & 43.5 & 33.31 & 43.74 \\
Pre-starter II & $36.81 \mathrm{a}$ & $20.75 \mathrm{~b}$ & 65.51 \\
Starter & $25.88 \mathrm{a}$ & $13.25 \mathrm{~b}$ & 58.53 \\
\hline
\end{tabular}

${ }^{1}$ Coefficient of variation. Means followed by different letters on the same line differ statistically by the Student's $t$-test at the $5 \%$ probability level. 
PUC is a protein indicator of animals and can be influenced by several factors, besides weight, age, gender, breed, and changes in protein intake and quality (BERSCHAUER et al., 1983), and the blood urea concentration is directly related to the protein levels of the diet and the E/P ratio of the diet (WITTWER et al., 1993).

The lower PUC values obtained for the ESWSversus SM-containing treatment can probably be explained by an improvement in the protein quality of the food, due to the extrusion process and the greater inclusion of synthetic amino acids in the diet. Oliveira et al. (2004) reported that for the reduction of nitrogen excretion by the animals, diets with low CP level could be used with amino acid supplementation, thereby reducing PUC.

\section{Economic feasibility}

The economic analysis data (Table 7) considered the cost of SM as R $\$ 1.35$ per $\mathrm{kg}$, and the price of ESWS also R\$1.35 per $\mathrm{kg}$. The feed cost per kilogram of live weight gain increased $(P<0.05)$ in the starter phase when ESWS replaced 100\% SM.

Table 7. Cost of feed per kilogram, diet cost per kilogram of pig produced (DC), economic efficiency index (EEI) and cost index (CI) of pigs in different experimental phases fed diets containing soybean meal (SM) and extruded semiwhole soybean (ESWS).

\begin{tabular}{|c|c|c|c|}
\hline \multicolumn{4}{|c|}{ Treatments } \\
\hline Item & SM & ESWS & $C V^{1}, \%$ \\
\hline \multicolumn{4}{|c|}{ Pre-starter I } \\
\hline Diet $\cos ^{2}, \mathbf{R} \$ / \mathbf{k g}$ & 2.98 & 2.93 & - \\
\hline $\mathrm{DC}^{3}, \mathrm{R} \$ / \mathrm{kg}$ body weight gain & 4.48 & 3.86 & 29.57 \\
\hline EEI & 86 & 100 & - \\
\hline CI & 116 & 100 & - \\
\hline \multicolumn{4}{|c|}{ Pre-starter II } \\
\hline Diet $\cos ^{2}, \mathbf{R} \$ / \mathbf{k g}$ & 2.28 & 2.27 & - \\
\hline $\mathrm{DC}^{3}, \mathrm{R} \$ / \mathrm{kg}$ body weight gain & 3.51 & 3.73 & 12.70 \\
\hline EEI & 100 & 94 & - \\
\hline CI & 100 & 106 & - \\
\hline \multicolumn{4}{|c|}{ Starter } \\
\hline Diet $\cos ^{2}, \mathrm{R} \$ / \mathbf{k g}$ & 1.13 & 1.17 & - \\
\hline $\mathrm{DC}^{3}, \mathrm{R} \$ / \mathrm{kg}$ body weight gain & $1.79 b$ & $2.07 \mathrm{a}$ & 11.60 \\
\hline EEI & 100 & 86 & - \\
\hline CI & 100 & 116 & - \\
\hline
\end{tabular}

${ }^{1}$ Coefficient of variation. ${ }^{2}$ Cost of $1 \mathrm{~kg}$ of feed. ${ }^{3} \mathrm{Cost}$ per $\mathrm{kg}$ of live weight gain in the period. Means on the same line followed by different letters are statistically different $(P<0.05)$.

Li et al. (1990) stated that the use of SM in diets or correctly-processed soybean is directly related to the availability of each product and the economic factors involved, all of which show similar performances in the pigs.
Only in the starter phase was the cost of the kilogram of feed slightly higher when ESWS rather than SM was used, explaining the poorer FC of the treatment that contained ESWS. A direct consequence of this observation was the dramatic 
increase in feed cost per kilogram of live weight, contributing to generate the most expensive feed in this phase.

The results of this economic analysis differ from the study by Ludke et al. (2007) that concluded ESWS provided a better economic result when comparing some types of processing, besides bringing similar results to the other types of processing for the performance of the animals.

\section{Conclusions}

The ESWS was shown to be an alternative source of energy and provide adequate protein for piglet feeding, as it presented good nutritional values, and a ME content of $4,019 \mathrm{kcal} / \mathrm{kg}$ of the natural matter. The 100\% replacement of SM by ESWS does not change the DWG and ADFI of piglets but worsens both the FC in the total period and economic results.

\section{Acknowledgments}

This study was financed in part by the Coordenação de Aperfeiçoamento de Pessoal de Nível Superior Brasil (CAPES) - Finance Code 001.

\section{References}

BELLAVER, C.; FIALHO, E. T.; SILVA PROTAS, J. F. da; GOMES, P. C. Radícula de malte na alimentação de suínos em crescimento e terminação. Pesquisa Agropecuária Brasileira, Brasília, v. 20, n. 8, p. 969-974, 1985.

BELLAVER, C.; SNIZEK JÚNIOR, P. N. Processamento da soja e suas implicações na alimentação de suínos e aves. In: CONGRESSO BRASILEIRO DE SOJA, 1999, Londrina. Anais... Londrina: EMBRAPA Soja, 1999. p. 183-199. (EMBRAPA Soja. Documentos, 124).

BERSCHAUER, F.; CLOSE, W. H.; STEPHENS, D. $B$. The influence of protein: energy value of the ration and level of feed intake on the energy and nitrogen metabolism of the growing pig. 2. $\mathrm{N}$ metabolism at two environmental temperatures. British Journal of Nutrition, Cambridge, v. 49, n. 2, p. 271-283, 1983. DOI: $10.1079 /$ BJN19830033
BERTIPAGLIA, L. M. A.; MELO, G. M. P. de; SUGOHARA, A.; MELO, W. J. de; BERTIPAGLIA, L.A. Alterações bromatológicas em soja e milho processados por extrusão. Revista Brasileira de Zootecnia, Piracicaba, v. 37 , n. 11 , p. 2003-2010, 2008. DOI: 10.1590/S151635982008001100016

BERTOL, T. M.; MORES, N.; LUDKE, J. V.; FRANKE, M. R. Proteínas da soja processadas de diferentes modos em dietas para desmame de leitões. Revista Brasileira de Zootecnia, Piracicaba, v. 30, n. 1, p. 150-157, 2001. DOI: 10.1590/S1516-35982001000100022

BRUMANO, G.; GATTÁS, G. Soja integral extrusada na alimentação de aves e suínos. Revista Eletrônica Nutritime, Viçosa, v. 1, n. 3, p. 134-146, 2004.

BUTOLO, J. E. Qualidade de ingredientes na alimentação animal. 2. ed. Campinas: Mundo Agro Editora, 2010. 430 p.

CAI, Y.; ZIMMERMAN, D. R.; EWAN, R. C. Diurnal variation in concentrations of plasma urea nitrogen and amino acids in pigs given free access to feed or fed twice daily. Journal of Nutrition, Bethesda, v. 124, n. 7, p. 1088-1093, 1994. DOI: 10.1093/jn/124.7.1088

CASTILLO, W. L.; KRONKA, R. N.; BARBOSA, H. P.; THOMAZ, M. C.; GOMES da SILVA, L. P.; RIBEIRO, P. R.; CARVALHO, L. E.; TRINDADE NETO, M. A. Efeito da utilização da soja semi-integral extrusada sobre o desempenho e as características das carcaças de suínos. ARS Veterinária, Jaboticabal, v. 17, n. 2, p. 137-143, 2001.

FEDALTO, L. M.; TULESKI, G. L. R.; WARPECHOWSKI, M. B.; BRAGA, T. Ração de farelo de soja e de soja integral extrusada e diferentes níveis de substituição do milho por titricale na alimentação animal.

I. Desempenho no crescimento de suínos. Archives of Veterinary Science, Curitiba, v. 4, n. 1, p. 65-67, 1999. DOI: 105380/avs.v4il.3782

GOMES, M. F. M.; BARBOSA, H. P.; FIALHO, E. T.; FERREIRA, A. S.; LIMA, G. J. M. M. de. Análise econômica da utilização do triguilho para suínos. Concórdia: EMBRAPA - Centro Nacional de Pesquisa de Suínos e Aves, 1991. (Comunicado técnico, 179).

LEITE, P. R. de S. da C.; MENDES, F. R.; PEREIRA, M. L. R.; LACERDA, M. J. R. Limitações da utilização da soja integral e farelo de soja na nutrição de frangos de corte. Enciclopédia Biosfera, Goiânia, v. 8, n. 15, p. 1138-1157, 2012.

LI, D. F.; NELSSEN, J. L.; REDDY, P. G.; BLECHA, F.; HANCOCK, J. D.; ALLEE, G. L.; GOODBAND, R. D.; KLEMM, R. D. Transient hypersensitivity to 
soybean meal in the early-weaned pig. Journal of Animal Science, Champaign, v. 68, n. 6, p. 1790-1799, 1990. DOI: $10.2527 / 1990.6861790 x$

LUDKE, M. do C. M. M.; LIMA, G. J. M. M. de; LANZNASTER, M.; ARDIGÓ, R. Soja integral processada de diferentes formas para uso em dietas para suínos em crescimento e terminação. Revista Brasileira de Zootecnia, Piracicaba, v. 36, n. 5, p. 1566-1572, 2007. DOI: $10.1590 / \mathrm{S} 1516-35982007000700015$

MATTERSON, L. D.; POTTER, L. M.; STUTZ, M. W.; SINGSEN, E. P. The metabolizable energy of feed ingredients for chickens. Storrs: University of Connecticut, Agricultural Experiment Station, Research Report, Connecticut, v. 7, n. 1, p. 11-14, 1965.

MENDES, W. S.; SILVA, I. J.; FONTES, D. O.; RODRIGUEZ, N. M.; MARINHO, P. C.; SILVA, F. O.; AROUCA, C. L. C.; SILVA, F. C. O. Composição química e valor nutritivo da soja crua e submetida a diferentes processamentos térmicos para suínos em crescimento. Arquivo Brasileiro de Medicina Veterinária e Zootecnia, Belo Horizonte, v. 56, n. 2, p. 207-213, 2004. DOI: 10.1590/S0102-09352004000200011

MOREIRA, I.; ROSTAGNO, H. S.; COELHO, D. T.; COSTA, P. M. A.; TAFURI, M. L. Determinação dos coeficientes de digestibilidade, valores energéticos e índices de controle de qualidade do milho e soja integral processados a calor. Revista Brasileira de Zootecnia, Piracicaba, v. 23, n. 6, p. 916-929, 1994.

OLIVEIRA, G. C. de; MOREIRA, I.; FURLAN, A. C.; BASTOS, A. O.; FRAGA, A. L. Efeito das dietas de baixo teor de proteína bruta, suplementadas com aminoácidos, para leitões machos castrados (15 a $30 \mathrm{~kg})$. Revista Brasileira de Zootecnia, Piracicaba, v. 33, n. 6, p. 17471757, 2004. DOI: 10.1590/S1516-35982004000700013

PEKAS, J. C. Versatile swine laboratory apparatus for physiologic and metabolic studies. Journal of Animal Science, Champaign, v. 27, n. 5, p. 1303-1306, 1968. DOI: $10.2527 /$ jas $1968.2751303 x$
REZENDE，W. O.; DONZELE，J. L.; OLIVEIRA, R. F. M. de; ABREU, M. L. T. de; FERREIRA, A. S.; SILVA, F. C. de O.; APOLÔNIO, L. R. Níveis de energia metabolizável mantendo a relação lisina digestível: caloria em rações para suínos machos castrados em terminação. Revista Brasileira de Zootecnia, Piracicaba, v. 35 , n. 3 , p. $1101-1106,2006$. DOI: $10.1590 / \mathrm{S} 1516-$ 35982006000400022

ROSTAGNO, H. S.; ALBINO, L. F. T.; DONZELE, J. L.; GOMES, P. C.; OLIVEIRA, R. F. de; LOPES, D. C.; FERREIRA, A. S.; TOLEDO BARRETO, S. L. de. Tabelas brasileiras para aves e suínos: composição de alimentos e exigências nutricionais. 3. ed. Viçosa, MG: UFV, Departamento de Zootecnia, 2011. p. 252.

SAKOMURA, N. K.; DEL BIANCHI, M.; PIZAURO JÚNIOR, J. M.; CAFÉ, M. B.; FREITAS, E. R. Efeito da idade dos frangos de corte sobre a atividade enzimática e digestibilidade dos nutrientes do farelo de soja e da soja integral. Revista Brasileira de Zootecnia, Piracicaba, v. 33 , n. 4 , p. $924-935$, 2004. DOI: 10.1590/S151635982004000400013

SAKOMURA, N. K.; ROSTAGNO, H. S. Métodos de pesquisa em nutrição de monogástricos. 2. ed. Jaboticabal: FUNEP Editora, 2016. 262 p.

SEBIO, L. Efeito de alguns parâmetros operacionais de extrusão nas propriedades físico-químicas da farinha de inhame (Dioscorea rotundata). 1996. Dissertação (Mestrado em Engenharia de Alimentos) - Universidade Estadual de Campinas, Campinas.

SILVA, D. J.; QUEIROZ, A. C. de. Análise de alimentos: métodos químicos e biológicos. 2. ed. Viçosa, MG: Imprensa Universitária, 2002. 235 p.

THOMAZ, M. C.; SILVEIRA, A. C.; KRONKA, R. N.; KRONKA, S. N.; BUDIÑO, F. E. L. Digestibilidade da soja semi-integral extrusada para leitões na fase inicial. Ciência Animal Brasileira, Goiânia, v. 13, n. 3, p. 290297, 2012. DOI: 10.5216/cab.v13i3.14403

WITTWER, F.; REYES, J.M.; OPITZ, H.; CONTRERAS, P. A.; BÖLMWALD, T. M. Determinación de úrea en muestras de leche de rebaños bovinos para el diagnóstico de desbalance nutricional. Archivos de Medicina Veterinária, Curitiba, v. 25, n. 2, p. 165-172, 1993. 